\title{
SANDFLY SPECIES COMPOSITION ALONG AN ALTITUDINAL TRANSECT IN SOUTHERN SINAI, EGYPT ${ }^{1}$
}

\author{
3. M. EL SAWAF*, A. SHOUKRY*, S. EL SAID*, R. P. LANE**, \\ M. A. KENAWY*, J. C. BEIER***, S. ABDEL SATTAR*
}

\begin{abstract}
SUMMARY. Sandflies were sampled in three areas of Southern Sinai, representing different ecological conditions and defined by altitudes. Of 489 specimens collected, 486 sandflies were identified: Phlebotomus papatasi, $P$. bergeroti, $P$. alexandri, P. sergenti, $P$. kazeruni, $P$. orientalis, $P$. arabicus, P. major, Sergentomyia tiberiadis, S. adleri/clydei, S. schwetzi, S. palestinensis, S. fallax and $S$. christophersi. Sandfly community composition and relative species abundance differed in the three areas and included two species in Abu Rudeis (on coast), 13 species in Feiran oasis and 12 species in St. Catherine (highest altitude). Species composition also differed bet ween wild and peridomestic habitats in each area, with species diversity greater in wild habitats.
\end{abstract}

Key-bords: Sandflies. Altitude. Sinai.

\section{Composition de la faune des Phlébotomes selon un transect altitudinal du Sinai méri- dional.}

RÉSUMÉ. Les Phlébotomes ont été échantillonnés dans trois territoires du Sud du Sinaï, présentant des conditions écologiques et des altitudes différentes. Sur 489 exemplaires collectés, 486 ont été identifiés : Phlebotomus papatasi, $P$. bergerosti, $P$. alexandri, $P$. sergenti, $P$. kazeruni, $P$. orientalis, P. arabicus, P. major, Sergentomyia tiberiadis, S. adleri/clydei, S. schwetzi, S. palestinensis, S. fallax et $S$. christophersi.

La composition des populations de Phlébotomes et l'abondance relative des espèces diffèrent dans les trois territoires considérés. Deux espèces sont reconnues à Abou Roudeis (sur le littoral), treize dans l'oasis de Feiran et 12 à Sainte-Catherine (à l'altitude la plus élevée). Le spectre des espèces varie dans chaque territoire, selon que le milieu est non habité ou mis en culture, sauvage ou péridomestique, avec une densité plus grande dans les zones non humanisées.

Mots-clés : Phlebotomus. Altitude. Sinaï.

1. This study was supported by research contract entitled: "Epidemiology and Control of Arthropod-Borne Diseases in Sinai "between the Egyptian Academy of Scientific Research and Technology and the Ain Shams Research and Training Center on Vectors of Diseases, Cairo, Egypt. The study was also supported by research contract entitled: "Epidemiology and Control of Arthropod-Borne Diseases in Egypt NO1 AI 22667 "between the National Institute of Allergy and Infectious Diseases (NIAID), National Institutes of Health (NIH), Bethesda Maryland, USA, and the Ain Shams Research and Training Center on Vectors of Diseases, Cairo, Egypt.

* Research and Training Center on Vectors of Diseases, Ain Shams University, Abbassia, Cairo, Egypt.

** London School of Hygiene and Tropical Medicine University of London, Department of Entomology.

*** National Institutes of Health (NIAID) resident consultant to Ain Shams Center.

Accepté le 24 avril 1987. 


\section{Introduction}

Sandfly species composition varies according to the ecological conditions in different parts of the world (Lane, 1986). In Egypt, seven sandfly species have been recorded Phlebotomus papatasi in Cairo (Willcoks, 1917), Sergentomyia squamipleuris in Sharkiya (Khalil, 1934), P. sergenti in Cairo (Theodor, 1948), Sergentomyia tiberiadis in Aswan (Hassan, 1968), S. palestinensis in Kharga oasis and S. minuta in Cairo (Zein El Dine, 1972) and Phlebotomus langeroni in El Agamy, Alexandria (El Sawaf et al., 1984). Recently, Lane (1986) reviewed the sandfly fauna of Egypt and increased this to 21 species: 8 Phlebotomus and 13 Sergentomyia.

Biogeographically, Egypt can be divided into three zones which differ floristically and faunistically, Lower Egypt and Northern Sinai, Upper Egypt and Southern Sinai (Lane, 1986). The Southern triangle of Sinai is the most mountainous zone of the peninsula, the geomorphology of S. Sinai varying between high mountainous rocky areas and scattered valleys (Hume, 1925 and Shata, 1950) suggesting that the sandfly fauna of this area is distinct from that of N. Sinai and the rest of Egypt.

Sandflies have not been extensively studied in S. Sinai but in N. Sinai $P$. papatasi and S. antennala were recorded (Lane, 1986). Until recently, neither cutaneous nor visceral leishmaniasis was considered common in Egypt and were only known from occasional clinically diagnosed cases. Morsy et al. (1982) and Rifaat et al. (1983a) have shown cutaneous leishmaniasis to be more widespread than previously thought. Human visceral leishmaniasis was detected for the first time in Egypt, from El Agamy, a suburb of Alexandria governorate (Tewfik et al., 1983). Available epidemiological evidence indicates that $P$. langeroni is the probable vector (El Sawaf et al., 1984; Beier el al., 1986, 1 and 3 and El Said et al., 1986).

In Sinai, 27 cases of cutaneous leishmaniasis have only recently been recorded by Bassili et al. (1983) but there is no corresponding information on sandflies.

The study of the sandfly fauna of S. Sinai examines species composition along an altitudinal transect focusing on three principal ecological zones.

\section{Materials and methods}

\section{DESCRIPTION OF THE STUDYING AREAS}

Southern Sinai was divided into three altitudinal zones.

a) Saint-Catherine, which lies in the center of S. Sinai with an altitude of 1,500-2,500 $\mathrm{m}$ in height (Max. Temp. $17^{\circ} \mathrm{C}$ in August and Min. Temp. $0^{\circ} \mathrm{C}$ in January, mean R. H. of $33 \%$ and mean rainfall of $62 \mathrm{~mm} /$ year), b) Feiran oasis (Wadi Feiran), which lies about the mid-way, between Saint Catherine and Abu Rudeis, with an altitude of 200-500 $\mathrm{m}$ in height (Max. Temp. $22^{\circ} \mathrm{C}$ in August 
and Min. Temp. $14^{\circ} \mathrm{C}$ in January, mean R. H. of $42 \%$, and mean rainfall of $31 \mathrm{~mm} /$ year, and c) Abu Rudeis, which lies north east of St. Catherine and Feiran oasis, with an altitude of less than $20 \mathrm{~m}$ in height (Max. Temp. 29.6 $\mathrm{C}$ in August and Min. Temp. $16^{\circ} \mathrm{C}$ in January, mean R. H. of $58 \%$ and mean rainfall of $20.5 \mathrm{~mm} /$ year).

\section{SAMPLING}

At each of the three studying zones, sandflies were sampled both around houses (peridomestic sites) and at about $4 \mathrm{~km}$ from a village or settlement (wild sites). Sampling was carried out using the sticky trap technique as described by Kirk and Lewis (1940), Chemical light/sticky trap and CDC light trap (Sudia and Chamberlain, 1962).

In Saint Catherine, seven stations were chosen for this study. A total of 303 sticky traps, 10 chemical light/sticky trap and one CDC light trap were used at different habitats.

In Feiran oasis, 5 stations were selected for sandflies collection. A total of 373 sticky traps; 9 chemical light/sticky traps and 2 CDC light traps were used at different habitats.

In Abu Rudeis, collections were performed in only three selected stations. An estimated number of 175 sticky traps, 5 chemical light/sticky trap were used at different habitats.

Collections from the three different zones were performed throughout six successive days, in August, 1984.

\section{Mounting AND IDENTIFICATION}

Collected samples were placed in $70 \%$ alcohol labelled and transferred to the Ain Shams Center for mounting and identification. Female sandflies that contained blood were cleared in chloral hydrate solution, before being mounted. Separated heads and abdomens were mounted in Puri's medium using the technique described by Hopkins (1936). Identification of the sandfly species was carried out by Dr. Bahira El Sawaf, in the British Museum (Natural History) London, and voucher specimens were deposited there.

\section{Results}

During the six day-trip to southern Sinai, a total of 489 phlebotomine sandflies was collected from the three localities: Saint Catherine; Feiran oasis; and Abu Rudeis. Of the collected specimens, 486 flies were identified as 8 Phlebotomus and 6 Sergentomyia and only one Phlebotomus and two Sergentomyia could not be identified.

In Saint Catherine, a total of 226 flies (161 Phlebotomus and 65 Sergentomyia) 
was collected from the peridomestic and wild sites. The species composition within the genus Phlebolomus was similar in peridomestic and wild sites except for $P$. major which was captured as one male near a hotel $6 \mathrm{~km}$ north east of 'Saint Catherine, whereas the species composition within the genus Sergentomyia was rather higher in wild sites than the peridomestic sites (table I).

In Feiran oasis (Wadi Feiran), a total of 261 flies (161 Phlebotomus and 100 Sergentomyia) were collected from both peridomestic and wild sites. The species composition of the peridomestic sites in Feiran oasis was similar to that of the wild sites except for $P$. sergenti and $P$. arabicus which were only found in the peridomestic sites (table I).

$\mathrm{Abu}$ Rudeis is omitted from the table since all collections were negative for sandflies from peridomestic sites, while in the wild sites only two flies, $P$. alexandri and $P$. sergenti, were caught.

TABLE I. - Sandfly species composition in peridomestic and wild sites in areas of different altitudes in Southern Sinai.

\begin{tabular}{|c|c|c|c|c|c|c|c|c|}
\hline \multirow[t]{4}{*}{ Species } & \multicolumn{4}{|c|}{$\begin{array}{l}\text { Saint Catherine } \\
(>1500 \mathrm{~m})\end{array}$} & \multicolumn{4}{|c|}{$\begin{array}{c}\text { Feiran Oasis } \\
(200-500 \mathrm{~m})\end{array}$} \\
\hline & \multicolumn{2}{|c|}{ Wild } & \multicolumn{2}{|c|}{$\begin{array}{l}\text { Peri- } \\
\text { domestic }\end{array}$} & \multicolumn{2}{|c|}{ Wild } & \multicolumn{2}{|c|}{$\begin{array}{l}\text { Peri- } \\
\text { domestic }\end{array}$} \\
\hline & \multicolumn{2}{|c|}{ No flies } & \multicolumn{2}{|c|}{ No flies } & \multicolumn{2}{|c|}{ No flies } & \multicolumn{2}{|c|}{ No flies } \\
\hline & q & o & & $b^{3}$ & & $\hat{3}$ & & 0 \\
\hline \multicolumn{9}{|l|}{ Phlebotomus } \\
\hline papatasi Scopoli & - & - & - & 一 & 一 & 1 & $\overline{10}$ & 1 \\
\hline bergeroti Parrot & $\ldots$ & - & - & - & - & 2 & 16 & 98 \\
\hline alexandri Sinton & 1 & 2 & 2 & 3 & 1 & 2 & 1 & - \\
\hline sergenti Parrot & 2 & 12 & 39 & 36 & - & - & 4 & 4 \\
\hline kazeruni Theodor and Mesghali & - & 14 & 2 & 14 & 1 & - & 2 & 5 \\
\hline orientalis Parrot & - & 12 & 1 & 4 & - & 9 & 4 & 6 \\
\hline arabicus Theodor & 4 & 9 & 1 & 2 & - & - & - & 3 \\
\hline major Annandale & - & - & - & 1 & - & 二 & - & - \\
\hline$s p$ & 一 & - & 一 & - & - & 1 & 一 & - \\
\hline Total & \multicolumn{4}{|c|}{161} & \multicolumn{4}{|c|}{161} \\
\hline \multicolumn{9}{|l|}{ Sergentomyia } \\
\hline $\begin{array}{l}\text { tiberiadis Adler, Theodor and } \\
\text { Lourie }\end{array}$ & 一 & 2 & 一 & 2 & 2 & 9 & 5 & 29 \\
\hline adleri/clydei Sinton & 2 & 1 & - & - & 8 & 4 & 9 & 3 \\
\hline $\begin{array}{l}\text { schwetzi Adler, Theodor and } \\
\text { Parrot }\end{array}$ & $\cdots$ & - & - & 2 & 一 & 1 & 3 & - \\
\hline palestinensis Adler, Theodor & - & 2 & 1 & - & - & 2 & 4 & 5 \\
\hline fallax Parrot & 20 & 26 & - & 3 & 5 & 8 & - & - \\
\hline christophersi Sinton & 1 & 2 & - & - & 一 & 1 & 1 & - \\
\hline$s p$ & - & 1 & - & 一 & - & - & - & 一 \\
\hline$s p$. & - & 一 & - & 一 & 1 & 一 & 一 & - \\
\hline Total & \multicolumn{4}{|c|}{65} & \multicolumn{4}{|c|}{100} \\
\hline
\end{tabular}


The sandfly composition is remarkably different in Saint Catherine and Feiran oasis than in Abu Rudeis. In Saint Catherine, both Phlebolomus and Sergentomyia species were present except $P$. papalasi and $P$. bergeroti. In Feiran oasis, all species were recorded except $P$. major. In Abu Rudeis, only two Phlebotomus species, $P$. alexandri and $P$. sergenti, were present.

Within the genus phlebotomus, $P$. major is the only species collected exclusively in peridomestic sites, while all other species could be found in peridomestic and wild sites considerably, e. g. $P$. bergeroti and $P$. sergenti were collected in large numbers in peridomestic than in wild areas. Whereas, within the genus Sergentomyia the species composition was similar in each site and $S$. fallax showed a tendency for wild areas based on the number collected in wild (table I).

\section{Discussion}

The sandfly composition of the southern Sinai suggests a marked affinity with the fauna of the Arabian Peninsula (Lewis and Buttiker, 1982), particularly Asir, Yeman (Lewis, 1974b) and to a lesser but still significant extent, to the highlands of eastern Africa.

It is of interest to note that there is a remarkable difference in sandfly species composition in Saint Catherine and Feiran oasis than in Abu Rudeis which is presumably due to the difference in altitude at the three localities.

The peridomestic character of $P$. papatasi is not clear in southern Sinai since only a small number was collected. Its presence in wild areas confirmed that this species is not purely domestic. Similar conditions were observed in Saudi Arabia by Buttiker et al. (1982).

The occurrence of $P$. major in Saint Catherine is consistent with the habitat characteristics of this species group. $P$. major is only abundant at altitude above $300 \mathrm{~m}$, in Greece (Leger et al., 1979).

$P$. bergeroti and $P$. sergenti that were collected both from peridomestic and wild areas constituted the highest percentage of phlebotomine sandflies collected from southern Sinai. Both are suspected vectors of cutaneous leishmaniasis in other parts of the world (Buttiker et al., 1982 and Molyneux, 1977).

$P$. kazeruni that was encountered both in peridomestic and wild sites in southern Sinai at high altitude, occurs only in low rocky deserts in Afghanistan (Artemiev, 1978) and is found in remote wadis and hills in Saudi Arabia (Buttiker and Lewis, 1984). Recently this species was found at relatively high altitude in Maroc (Rioux el al., 1986).

Some sandfly species identified throughout this study, are known vectors of leihsmaniasis. As for cutaneous leishmaniasis, $P$. alexandri in north Africa (Dedet, 1979) and P. sergenti in U. S. S. R. (W. H. O., 1984). As for visceral leishmaniasis $P$. orientalis in the Sudan (Hoogstraal and Hyneman, 1969) and P. major in Greece (Leger el al., 1979).

This study was undertaken as a first step in examining the sandfly species 
composition. Further studies are needed to define habitat characteristics of each species and to monitor for Leishmania transmission, in conjunction with changing ecological conditions due to changing land-use and settlements in southern Sinai.

Acknowledgements. We are grateful to the Egyptian Ministry of Health for kindly facilitating this research. We thank the following members of the Ain Shams staff who expertly assisted with field and laboratory work: Mr. Gamal El Kady, Mr. Shaaban Ismail, Mrs. Hala Kassem and Dr. Magdi Shehata for the analysis of data and revision of the manuscript.

We thank Dr. J. A. Rioux (Laboratoire d'Écologie médicale, Faculté de Médecine, Montpellier) for helpful discussions and comments on the manuscripts.

\section{REFERENCES}

Artemiev M. M. : Sandflies (Diptera, Psychodidae, Phlebotominae) of Afghanistan Mimeographed Document Malaria and Leishmaniasis Institutes Kabul, 1978, 4, 87.

Bassili W. R., Morsy T. A., Michael S. A. : Specificity and sensitivity of indirect haemaggluti nation in patients with cutaneous Leishmaniasis. J. Egypt. Soc. Parasitol, 1983, 13, 291-295.

Beier J. C., El Sawaf B. M., Merdan A. I., El Said S., Doha S. : Sandflies (Diptera: Psychodidae) associated with visceral leishmaniasis in El Agamy, Alexandria Governorate, Egypt. Part I: Population ecology. J. Med. Entomol., 1986, 23, 600-608.

Beien J. C., El Sawaf B. M., Morsy T. A., Merdan A. I., Rifant M. M., El Said S. : Sandflies (Diptera: Psychodidae) associated with visceral leishmaniasis in El Agamy, Alexandria Governorate, Egypt. Part III: Experimental Leishmania infections and vector status. J. Med. Entomol., 1986, 23,616-621.

Buttiker W., Al A Yed I. H., Alwabil A. H., Assalky H. S., Rashed A. M., Shareefi O. M. : Medical and applied zoology in Saudi Arabia. A preliminary study on leishmaniasis in two areas of the Asir Region. Fauna of Saudi Arabia, 1982, 4, 509-519.

Buttiker W., Lewis D. J. : Insects of Saudi Arabia. Some ecological aspects of Saudi Arabian Phlebotomine sandflies (Diptera: Psychodidae). Fauna of Saudi Arabia, 1984, 5, 479-530.

Dedet J. P. : Les leishmanioses en Afrique du nord. Bull. Inst. Pasteur, 1979, 73, 49-82.

El Sawaf B. M., Beier J. C., Hussein S. M., Kassem H. A., Sattar S. A. : Phlebotomus langeroni : a potential vector of Kala Azar in the Arab Republic of Egypt. Trans. R. Soc. Trop. Med. Hyg., 1984, 78, 421.

El Said S., Beier J. C., El Sawaf B. M., Doha S., El Kordy E. : Sandflies (Diptera: Psychodidae) associated with visceral leishmaniasis in El Agamy. Alexandria Governorate, Egypt. Part II: Field behavior. J. Med. Entomol., 1986, 23, 609-615.

Hassan Z. A. : Visceral leishmaniasis in U. A. R., M. D. Thesis. Ain Shams University, Cairo, $1968,207 \mathrm{p}$.

Hoogstraal H., Heyneman D. : Leishmaniasis in the Sudan Republic 30. Final epidemiologic report. Am. J. Trop. Med. Hyg., 1969, 18,1087-1210.

Hopkins G. H. E. : Mosquitoes of the Ethiopian Region. Part I: Larval bionomics and taxonomy of culicine larvae. Bull. Br. Mus. Nat. Hist. (Ent.), London, 1936, 250 p.

Hume W. F. : Geology of Egypt. Cairo Government Press Survey of Egypt, 1925, 1, 249-276.

Khalil M. B. : Dermal Leishmaniasis: A study of an endemic focus in Egypt. Arch. Schif. Tropen Hyg., 1934, 38, 417-433.

Kirk R., Lewis D. J. : Studies in Leishmaniasis in the Anglo-Egyptian Sudan. Part III: The sandflies (Phlebotomus) of the Sudan. Trans. R. Soc. Trop. Med. Hyg., 1940, 33, 623-634.

Lane R. P. : The sandflies of Egypt (Diptera: Phlebotominae). Bull. Br. Mus. Nat. Hist. (Ent.), $1986,52,1-35$.

Leger M., Saratsiotis A., Pesson B., Leger P. : La Leishmaniose en Grèce. Résultats d'une enquête entomologique effectuée en juin 1977. Ann. Parasitol. Hum. Comp., 1979, 54, 11-29.

LEwis D. J. : The phlebotomid sandflies of Yemen Arab Republic. Tropenmed. Parasitol., 1974, $25,187-197$.

LEwis D. J., Butriker W. : Insects of Saudi Arabia. The taxonomy and distribution of Saudi Arabian Phlebotomine sandflies (Diptera: Psychodidae). Fauna of Saudi Arabia, 1982, 4, 353-397.

MolyneuX D. A. : Vector relationships in the Trypanosomidae. Adv. Parasitol., 1977, 15, 43-82.

Morsy T. A., Musallam R. A. Z., El Shabrawy M. W., Hassan H. I. : Parasitic infections in Ismailiyia Governorate, Egypt. J. Egypt. Soc. Parasitol., 1982, 11, 147-156. 
RifaAt M. A., Morsy T. A., Michael S. A. : The presence of leishmaniasis antibodies in children in Tanta Governorate, Egypt. J. Egypt. Soc. Parasitol., 1983, 13, 1-7.

Rioux J. A., Velez I. D., Denial M., Dereure J., Perières J., Lanotte G., El Mellouki W. : Présence au Maroc de Phlebotomus (Paraphlebotomus) Kazeruni Theodor et Meschali, 1964. Ann. Parasitol. Hum. Comp., 1986, 61, 473-481.

Shata A. : Structural development of the Sinai Peninsula. Bull. Inst. Desert Egypt., 1950, 6, 117 p.

Sudia W. D., Chamberlain R. W. : Battery-operated light trap, an improved model. Mosq. News, 1962, 22, 126-129.

Tewfik S., Kassem S. A., Aref M. K., Awadalla H. N., Abadir A. : A preliminary report on two cases of visceral leishmaniasis in Egypt. Trans. R. Soc. Trop. Med. Hyg., 1983, 77, 334-335.

Theodor O.: On some sandflies (Phlebotomus) of the sergenti group in Palestine. Bull. Ent. Res., $1948,39,85-111$.

W. H. O.: The Leishmaniasis. Tech. Rep. Ser., 1984, $701 \mathrm{p}$.

Willcoks F. C. : Notes on some insects found in Egypt of medical and veterinary interest. Bull. Ent. Soc. Egypt., 1917, 10, 79-90.

Zein El Dine K. : Phlebotomidae (Diptera: Psychodidae) of Egypt. J. Egypt. Publ. Hlth. Ass., $1972,47,269-272$. 